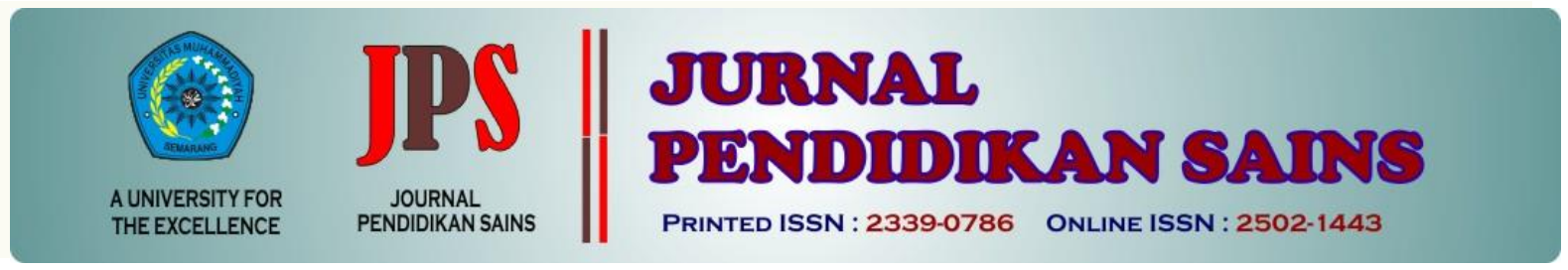

http://jurnal.unimus.ac.id/index.php/JPKIMIA

\title{
PENERAPAN MODEL PEMBELAJARAN BERBASIS MASALAH (PROBLEM BASED LEARNING ) DALAM MATA KULIAH MANAJEMEN LIMBAH B3
}

\author{
Oleh: \\ Hans Kristianto $^{1 *}$, Tedi Hudaya ${ }^{1}$ \\ ${ }^{1}$ Program Studi Teknik Kimia, Fakultas Teknologi Industri, \\ Universitas Katolik Parahyangan, Bandung, Indonesia
}

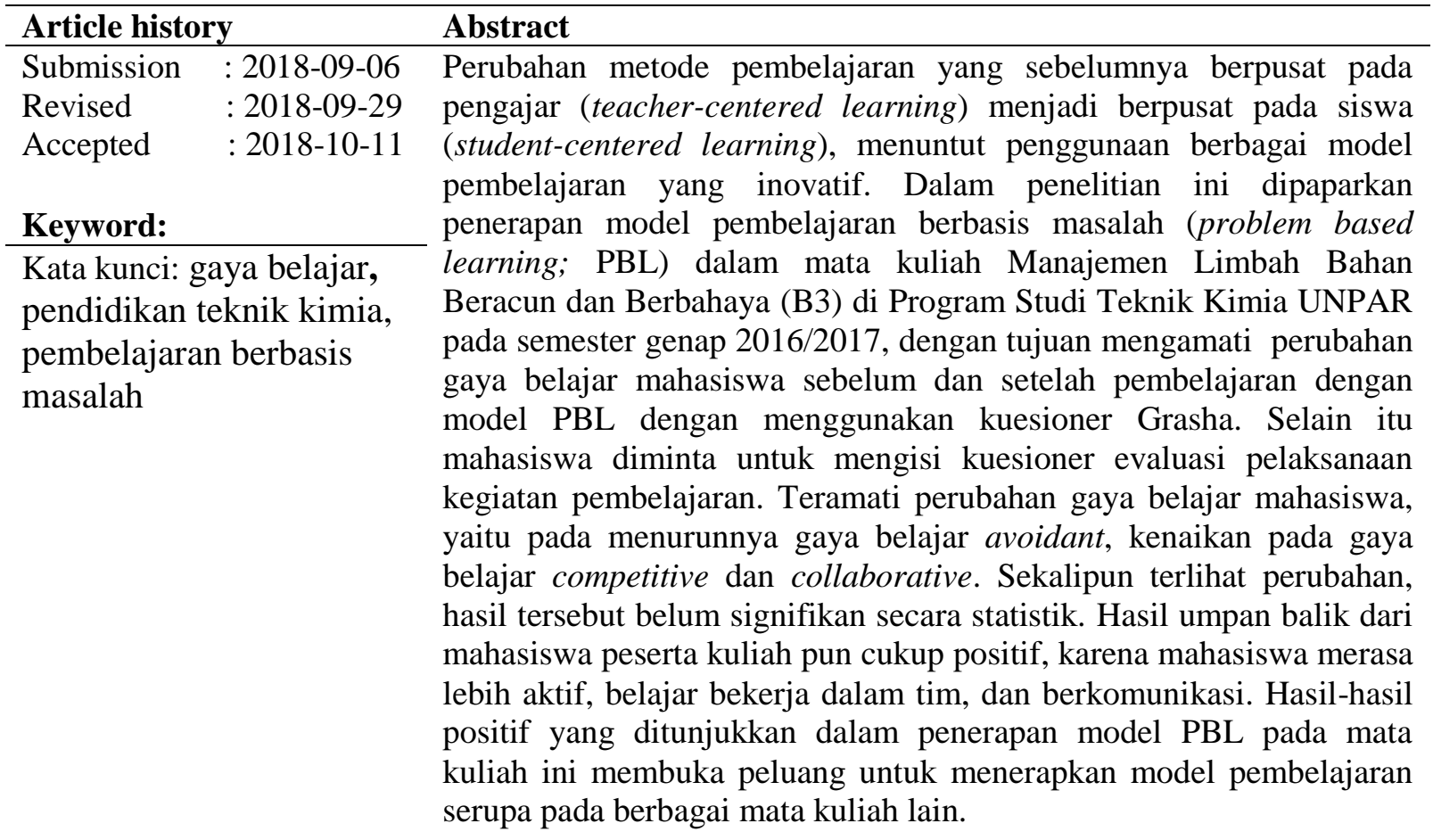

\section{Pendahuluan}

Pendidikan merupakan suatu proses yang dialami seseorang untuk dapat mengembangkan potensi diri, untuk memperoleh kekuatan aspek kognitif, afektif dan psikomotorik, secara spesifik termaktub dalam tujuan pendidikan tinggi dalam UU No 12 Tahun 2012 pasal 5, tentang Tujuan
Pendidikan Tinggi. Lebih lanjut, Kementerian Riset Teknologi dan Pendidikan Tinggi menekankan pentingnya capaian pembelajaran setiap lulusan perguruan tinggi. Hal ini tertuang dalam Kerangka Kualifikasi Nasional Indonesia (KKNI), di mana lulusan Sarjana (S-1) perlu diarahkan untuk mampu menguasai dasar ilmiah dan keterampilan, menemukan, memahami, menjelaskan, dan merumuskan cara

*Corresponding Author:

$\begin{array}{ll}\text { Nama } & \text { : Hans Kristianto } \\ \text { Lembaga } & \text { : Program Studi Teknik Kimia, Universitas Katolik Parahyangan } \\ \text { Email } & \text { : hans.kristianto@ unpar.ac.id }\end{array}$


penyelesaian masalah, menerapkan ilmu pengetahuan dan keterampilan untuk masyarakat, bersikap dan berperilaku baik dalam berkarya, serta mengikuti perkembangan ilmu pengetahuan sesuai bidangnya (Santoso et al., 2015). Sejalan dengan itu, organisasi profesi Teknik Kimia internasional, IChemE, merumuskan capaian pembelajaran bagi lulusan program studi Teknik Kimia yang terakreditasi IChemE, sebagai berikut (IChemE, 2017):

1. Menguasai kemampuan dasar dan prinsipil dalam Teknik Kimia

2. Memiliki kepekaan sosial, lingkungan, hukum, etis, keamanan (safety), ekonomi dalam praktek keinsinyuran

3. Menerapan kemampuan ilmiah dan teknis dalam memecahkan masalah secara kreatif dan inovatif

4. Memiliki kemampuan praktis melalui kerja lab, individu, tim, dan perancangan

5. Memiliki soft skills seperti komunikasi, pengaturan waktu, bekerja dalam tim, kemampuan menggunakan IT dan software, dsb.

Dalam rangka memenuhi capaian pembelajaran yang disampaikan di atas, perlu dilakukan perubahan, atau pelengkap, metode pembelajaran konvensional (teacher-centered), menjadi pembelajaran berpusat pada siswa (student-centered learning). Dalam penerapan pembelajaran berpusat pada siswa, siswa merasa terdorong dan berperan aktif dalam kegiatan belajar mengajar, serta mengembangkan diri dan keilmuannya. Hal ini sesuai dengan apa yang dibutuhkan oleh mahasiswa nanti pada dunia kerja, yang dikenal sebagai 21 st century skills meliputi creativity and innovation; communication and colllaboration; research and information fluency; critical thinking, problem solving and decision making; digital citizenship; technology operations and concepts (Larson \& Miller, 2012).

Pembelajaran berbasis masalah merupakan suatu metode pembelajaran berpusat pada mahasiswa di mana mahasiswa dipicu oleh masalah untuk mencari solusi terkait masalah yang diberikan secara berkelompok (Mulia \& Krisanti, 2012). Dalam proses mencari solusi tersebut, mahasiswa perlu mempelajari berbagai pengetahuan dasar yang dibutuhkan untuk merumuskan solusi dari masalah yang diberikan. Berdasarkan Hung, dkk (2008), pengetahuan dasar dan masalah yang diberikan bersifat resiprokatif. Hal ini diartikan bahwa pengetahuan dibangun berdasarkan stimulasi dari masalah, kemudian pengetahuan diterapkan untuk memecahkan masalah, dan seterusnya sampai diperoleh solusi (Hung, Jonassen, \& Liu, 2008).

Langkah-langkah yang ditempuh dalam metode pembelajaran berbasis masalah diajabarkan sebagai berikut (Felder \& Brent, 2003):

1. Dosen menyediakan suatu masalah kompleks, yang biasanya diambil masalah nyata. Masalah ini merupakan masalah yang harus diselesaikan mahasiswa (biasa disebut pemicu) sebagai media pembelajaran

2. Mahasiswa secara berkelompok melakukan analisa terhadap masalah yang diberikan, kemudian merumuskan isu-isu pembelajaran (pengetahuan dasar) yang dibutuhkan untuk mencari solusi masalah tersebut

3. Mahasiswa kemudian membagi-bagi isu pembelajaran yang telah dirumuskan, kemudian setiap mahasiswa diminta untuk mempelajari isu pembelajaran serta mempersiapkan suatu pemaparan untuk membagikan pengetahuan yang telah diperoleh terkait isu pembelajaran yang telah dipelajari. Sesi ini disebut sebagai sesi saling ajar, dan dilakukan pada pertemuan berikutnya.

4. Setelah melakukan sesi saling ajar, mahasiswa merumuskan solusi dari masalah/pemicu yang diberikan. Dalam tahap perumusan masalah ini dimungkinkan untuk kembali mencari pengetahuan (hubungan resiprokatif masalah-pengetahuan) sampai diperoleh solusi.

5. Kelompok mahasiswa kemudian mempersiapkan pemaparan untuk kemudian dipresentasikan di hadapan seluruh kelas.

Dalam metode pembelajaran berbasis masalah ini, dosen mengambil peran sebagai floating facilitator, yaitu fasilitator untuk menyediakan sarana untuk menunjang pembelajaran mahasiswa, model yang memberikan contoh untuk melakukan pembelajaran efektif, memberikan petunjuk, 
umpan balik, dan arahan kepada mahasiswa, serta sebagai narasumber jika dibutuhkan.

Pada penelitian ini, disajikan penerapan pembelajaran berbasis masalah pada mata kuliah Manajemen Limbah Bahan Beracun dan Berbahaya pada semester genap 2016/2017. Mata kuliah ini merupakan mata kuliah pilihan yang diambil mahasiswa tingkat tiga dan empat yang bersifat perluasan (broadening) terhadap pengetahuan mahasiswa. Perubahan gaya belajar mahasiswa sebelum dan setelah mengalami pembelajaran berbasis masalah akan diukur dengan menggunakan kuesioner Grasha (Novak, Shah, Wilson, Lawson, \& Salzman, 2006; Riechmann \& Grasha, 1974). Kuesioner Grasha membagi kecenderungan gaya belajar menjadi enam kriteria, yaitu independent, dependent, collaborative, competitive, participant, dan avoidant, yang dapat dijelaskan sebagai berikut (Riechmann \& Grasha, 1974):

1.Independent merujuk kepada mahasiswa yang lebih suka berpikir sendiri dan bekerja mandiri, selain memiliki kemandirian untuk mempelajari hal-hal yang dirasakan penting.

2.Dependent berarti mahasiswa yang relatif tidak menunjukkan keingintahuan terhadap materi yang dipelajari, serta hanya mempelajari hal-hal yang dibutuhkan. Mahasiswa tipe ini bergantung pada pengajar sebagai pemberi instruksi.

3. Collaborative merujuk pada mahasiswa yang secara aktif membagikan ide dan pengetahuannya untuk dapat belajar dengan efektif. Mahasiswa tipe ini melihat kelas sebagai media untuk berinteraksi.

4.Competitive ditunjukkan oleh mahasiswa yang memiliki keinginan untuk unggul dibandingkan dengan teman-teman di kelasnya. Mahasiswa ini menganggap bahwa kelas adalah suatu kompetisi di mana mahasiswa harus selalu unggul.

5.Participant merupakan gaya belajar mahasiswa yang menyukai kegiatan belajar mengajar dan berpartisipasi dalam setiap kegiatan pembelajaran.

6.Avoidant merupakan tipe mahasiswa tidak menyukai dan tidak tertarik dengan kegiatan pembelajaran tradisional di kelas.

\section{Metode Penelitian}

Jenis Penelitian

Penelitian ini menggunakan pendekatan kuantitatif deskriptif weak experiment, di mana diamati perubahan parameter kelas sebelum dan setelah pembelajaran (one group, pre test-post test).

\section{Waktu dan Tempat Penelitian}

Penelitian ini dilakukan di Program Studi Sarjana Teknik Kimia, Universitas Katolik Parahyangan (UNPAR), Bandung, dengan waktu antara pertengahan Januari hingga awal Mei 2017 (semester genap 2016/2017).

Target/Subjek Penelitian

Subjek penelitian adalah seluruh mahasiswa peserta mata kuliah pilihan Manajemen Limbah Bahan Beracun dan Berbahaya. Mata kuliah ini merupakan mata kuliah pilihan yang diambil oleh mahasiswa tingkat tiga dan empat.

Prosedur

Kegiatan pembelajaran berbasis masalah pada mata kuliah Manajemen Limbah B3 dilakukan melalui tahapan-tahapan sebagai berikut:

1. Tahap 1: melakukan restrukturisasi bahan dalam satuan acara perkuliahan (SAP)

2. Tahap 2: merumuskan masalah (pemicu) untuk kegiatan pembelajaran

3. Tahap 3: pelaksanaan kegiatan pembelajaran berbasis masalah. Kegiatan pembelajaran berbasis masalah dilakukan dengan rangkaian kegiatan tiga pertemuan sebagai berikut:

a.Pertemuan ke-1: kelompok mahasiswa mendiskusikan pemicu yang diberikan, kemudian merumuskan masalah serta isu-isu pembelajaran. Isu pembelajaran yang telah dirumuskan kemudian dibagi kepada setiap anggota kelompok untuk melakukan kegiatan belajar mandiri terhadap isu yang diberikan.

b.Pertemuan ke-2: mahasiswa melakukan sesi saling ajar dengan rekan sekelompoknya. Dari sesi ini kemudian mahasiswa berupaya merumuskan solusi dari pemicu (masalah).

c.Pertemuan ke-3: kelompok mahasiswa mempresentasikan hasil pembelajaran 
serta solusi dari pemicu di hadapan kelas.

Data, Intrumen, dan Teknik Pengumpulan Data

Evaluasi terhadap kegiatan belajar mengajar dilakukan dengan menggunakan kuesioner Grasha untuk melihat gaya belajar mahasiswa sebelum dan setelah kuliah dengan PBL (Novak et al., 2006). Berdasarkan rata-rata nilai yang diperoleh, kemudian dilihat kecenderungan setiap gaya belajar pada rentang rendah, sedang, atau tinggi, dengan kriteria yang disajikan di Tabel 1. Selain itu, mahasiswa juga diminta mengisi komentar terhadap kegiatan pembelajaran sebelum dan setelah pembelajaran, serta kuesioner evaluasi pelaksanaan pembelajaran berdasarkan Powell (2009).

Tabel 1. Rentang nilai gaya belajar (Novak et al., 2006)

\begin{tabular}{llll}
\hline Gaya & \multicolumn{2}{l}{ Rentang } & \\
\cline { 2 - 4 } belajar & Rendah & Sedang & Tinggi \\
\hline Independent & $1,0-2,7$ & $2,8-3,8$ & $3,9-5,0$ \\
Dependent & $1,0-2,9$ & $3,0-4,0$ & $4,1-5,0$ \\
Collaborative & $1,0-2,7$ & $2,8-3,4$ & $3,5-5,0$ \\
Competitive & $1,0-1,7$ & $1,8-2,8$ & $2,9-5,0$ \\
Participant & $1,0-3,0$ & $3,1-4,1$ & $4,2-5,0$ \\
Avoidant & $1,0-1,8$ & $1,9-3,1$ & $3,2-5,0$ \\
\hline
\end{tabular}

Macam data, bagaimana data dikumpulkan, dengan instrumen yang mana data dikumpulkan, dan bagaimana teknis pengumpulannya, perlu diuraikan secara jelas dalam bagian ini.

Teknik Analisis Data

Data dari kuesioner Grasha dianalisa dengan menggunakan paired t-test dengan hipotesis:

1. Ho: $\mu_{1}=\mu_{2}$

2. $\mathrm{H} 1: \mu_{1} \neq \mu_{2}$

dan tingkat kepercayaan $95 \%$.

\section{Hasil Penelitian dan Pembahasan}

\section{Restrukturisasi SAP dan Merumuskan Pemicu}

Sebelum kegiatan perkuliahan dimulai, dosen bertanggung jawab untuk mempersiapkan masalah yang akan menjadi bahan diskusi mahasiswa. Dalam kegiatan yang telah dilakukan, perlu dilakukan sedikit perubahan pada SAP di mana urutan materi yang dibahas ditukar sehingga dapat dikelompokkan menjadi satu masalah yang utuh. Untuk total 14 minggu perkuliahan (tidak termasuk ujian tengah dan akhir semester), kegiatan pembelajaran dengan PBL dibagi menjadi 2 masalah sebelum, dan 2 masalah setelah UTS. Pembagian pokok bahasan dan pemicunya disajikan pada Tabel 2.

Tabel 2. Pokok bahasan dan pemicu yang digunakan

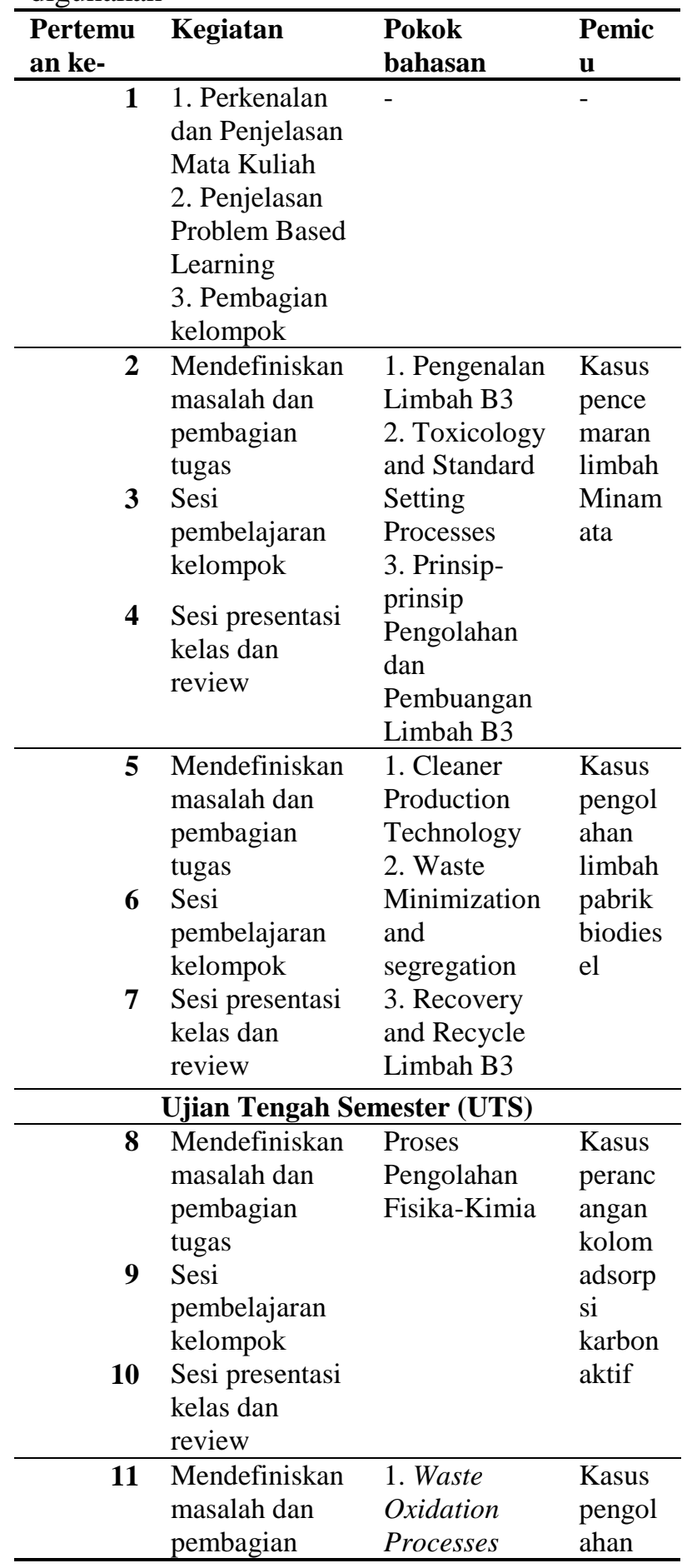




\begin{tabular}{|c|c|c|c|}
\hline $\begin{array}{l}12 \\
13\end{array}$ & $\begin{array}{l}\text { tugas } \\
\text { Sesi } \\
\text { pembelajaran } \\
\text { kelompok } \\
\text { Sesi presentasi } \\
\text { kelas dan } \\
\text { review }\end{array}$ & $\begin{array}{l}\text { 2. } \mathrm{AOP}: \\
\mathrm{UV} / \mathrm{H}_{2} \mathrm{O}_{2} \\
\text { 3. AOP : } \\
\mathrm{UV} / \mathrm{H}_{2} \mathrm{O}_{2} / \mathrm{O}_{3}\end{array}$ & $\begin{array}{l}\text { limbah } \\
\text { dengan } \\
\text { proses } \\
\text { oksida } \\
\text { si }\end{array}$ \\
\hline 14 & $\begin{array}{l}\text { 1. Review } \\
\text { seluruh } \\
\text { kegiatan } \\
\text { pembelajaran } \\
\text { 2. Kuliah } \\
\text { penutup }\end{array}$ & $\begin{array}{l}\text { Pengolahan } \\
\text { limbah B3 } \\
\text { terpadu } \\
\text { (PPLI) }\end{array}$ & - \\
\hline
\end{tabular}

\section{Evaluasi Kegiatan Belajar Mengajar}

Sebelum dan setelah kegiatan belajar mengajar, mahasiswa diminta untuk mengisi kuesioner Grasha untuk melihat apakah penerapan PBL menyebabkan perubahan gaya belajar mahasiswa. Kuesioner Grasha merupakan suatu alat ukur yang digunakan untuk mengetahui dan menggolongkan karakter mahasiswa, dan kaitannya terhadap metode pengajaran yang sesuai. Gaya belajar mahasiswa peserta kuliah PBL disajikan pada Tabel 3. Nilai yang disajikan pada Tabel 3 merupakan rata-rata, disertai standard deviasinya, dari seluruh peserta kelas, dengan rentang yang ditentukan oleh Grasha. Jika dilihat pada gaya belajar sebelum PBL, maka dapat dilihat secara umum kelas ini bukan merupakan kelas yang ideal untuk penerapan PBL, karena nilai participant dan independent yang sedang. Padahal PBL paling cocok diterapkan bagi mahasiswa yang memiliki gaya belajar collaborative, participant, dan independent yang tinggi (Novak et al., 2006). Menurut Novak dkk (2006) perubahan dalam metode pembelajaran ini dapat menyebabkan "stress" pada beberapa minggu awal perkuliahan, di mana mahasiswa beradaptasi dengan pengalaman belajar yang baru. Pada akhir perkuliahan dengan PBL, terjadi perubahan nilai pada semua gaya belajar, hanya perubahan yang terlihat cukup besar pada penurunan pada nilai rata-rata gaya belajar avoidant, dan kenaikan pada gaya belajar competitive dan collaborative. Sekalipun terlihat perubahan nilai rata-rata dari gaya belajar Grasha tersebut, secara statistik perubahan sebelum dan setelah mahasiswa mengikuti proses pembelajaran berbasis masalah tidak signifikan secara statistik, ditunjukkan dengan nilai $\mathrm{p}$ yang lebih besar dari 0,05 . Hal ini diduga diakibatkan oleh pelaksanaan proses pembelajaran yang relatif singkat (4 bulan) dan dilakukan oleh mahasiswa tingkat akhir (tiga dan empat) yang sudah terbentuk gaya belajarnya sejak awal masuk perkuliahan.

Tabel 3. Perubahan nilai gaya belajar sebelum dan setelah menerapkan PBL

\begin{tabular}{lccccccc}
\hline \multirow{2}{*}{$\begin{array}{l}\text { Gaya } \\
\text { belajar }\end{array}$} & \multicolumn{3}{c}{ Sebelum PBL } & \multicolumn{3}{c}{ Setelah PBL } & p value \\
\cline { 2 - 7 } & Nilai & $\begin{array}{c}\text { Standard } \\
\text { Deviasi }\end{array}$ & Rentang & Nilai & $\begin{array}{c}\text { Standard } \\
\text { Deviasi }\end{array}$ & Rentang & \\
\hline Independent & 3.342 & 0.466 & Sedang & 3.433 & 0.634 & Sedang & 0.674 \\
Dependent & 3.625 & 0.416 & Sedang & 3.717 & 0.292 & Sedang & 0.525 \\
Collaborative & 3.583 & 0.327 & Tinggi & 3.825 & 0.384 & Tinggi & 0.081 \\
Competitive & 2.675 & 0.694 & Sedang & 2.867 & 0.523 & Tinggi & 0.504 \\
Participant & 3.067 & 0.579 & Sedang & 3.158 & 0.423 & Sedang & 0.736 \\
Avoidant & 3.408 & 0.605 & Tinggi & 3.167 & 0.566 & Tinggi & 0.313 \\
\hline
\end{tabular}

Evaluasi kegiatan PBL dilakukan pula dengan menggunakan kuesioner Powell (2009). Kuesioner Powell menggunakan nilai 1 untuk sangat tidak setuju, dan 5 untuk sangat setuju untuk setiap pernyataan. Berdasarkan evaluasi tersebut, dapat disimpulkan bahwa mahasiswa merasakan perbedaan penggunaan PBL dalam kegiatan belajar mengajar, terlebih mahasiswa setuju bahwa PBL membuat kuliah lebih aplikatif, serta melatih kerja kelompok. Akan tetapi mahasiswa juga merasakan tambahan beban, yang ditunjukkan dengan pada pertanyaan no 3 . Hal ini merupakan fenomena umum yang 
dirasakan oleh mahasiswa dalam pengalaman, terutama pertama kali, menggunakan PBL dalam perkuliahan (Novak et al., 2006). Peningkatan nilai gaya belajar competitive setelah PBL diduga diakibatkan oleh sistem penilaian per orangan baik oleh sejawat atau pun oleh dosen, sehingga menuntut mahasiswa untuk terlihat unggul dibanding rekan sekelompoknya. Kenaikan gaya belajar participant dan penurunan gaya belajar avoidant dari analisa Grasha di atas, didukung dengan jawaban pertanyaan 7,8 dan 9 , yang secara tidak langsung menunjukkan bahwa mahasiswa menikmati pekerjaan dengan kerja kelompok. Sejalan dengan itu, hal ini juga diungkapkan dalam kesan yang disampaikan oleh mahasiswa, disajikan pada Tabel 5.

\section{Simpulan dan Saran}

Simpulan

Kegiatan belajar mengajar dengan menggunakan metode PBL telah diterapkan pada mata kuliah Manajemen Limbah B3 semester genap 2016/2017. Berdasarkan kegiatan yang telah dilakukan, dapat dilihat dampak positif dalam gaya belajar mahasiswa, di mana terjadi penurunan pada gaya belajar avoidant, selain kenaikan pada gaya belajar competitive dan collaborative. Akan tetapi perubahan tersebut tidak signifikan secara statistik.

Saran

Sistem pembelajaran berbasis masalah dapat digunakan pada mata kuliah lain, dan perlu dicoba pada mahasiswa tingkat awal, selain dilakukan terus menerus di setiap semester untuk dapat memberikan perubahan yang signifikan.

Tabel 4. Kuesioner evaluasi pelaksanaan PBL (skala 1-5: sangat tidak setuju - sangat setuju) (Powell, 2009)

\begin{tabular}{lll}
\hline Pertanyaan & $\begin{array}{l}\text { Nilai } \\
\text { (SD) }\end{array}$ \\
\hline $\begin{array}{l}\text { 1. Kuliah ini diajarkan dalam } \\
\text { bentuk PBL, tetapi saya rasa tidak }\end{array}$ & 1,75 \\
berbeda dengan kuliah biasa. & \\
2. Saya rasa dengan bentuk PBL, & 3,67 \\
kuliah ini memberikan kesempatan & $(0,98)$ \\
untuk pembelajaran yang lebih & \\
aplikatif. \\
$\begin{array}{l}\text { 3. Menurut saya, format PBL } \\
\text { membuat kuliah ini lebih sulit }\end{array}$ & $(0,75)$ \\
\hline
\end{tabular}

daripada seharusnya.

4. Saya yakin nilai saya menjadi lebih baik karena menggunakan kuliah PBL. Jika dengan metode biasa, nilai saya akan lebih jelek.

5. Saya merasa bahwa saya memiliki pemahaman lebih terhadap masalah nyata setelah mengambil kuliah ini.

6. Saya TIDAK akan mengambil kuliah lain dengan format PBL.

7. Kerja tim menjadi pengalaman berharga, karena di dalam tim kami bekerja sama untuk menyelesaikan masalah.

8. Saya rasa grup saya memberikan diskusi yang baik sepanjang mengerjakan pemicu, dan diskusi tersebut menjadi bagian berharga dalam pembelajaran saya.

9. Kelompok saya tidak berfungsi dengan baik, sehingga saya mengerjakan lebih banyak tugas daripada seharusnya.

Keterangan: SD merupakan standard deviasi

Tabel 5. Harapan dan kesan mahasiswa sebelum dan setelah PBL

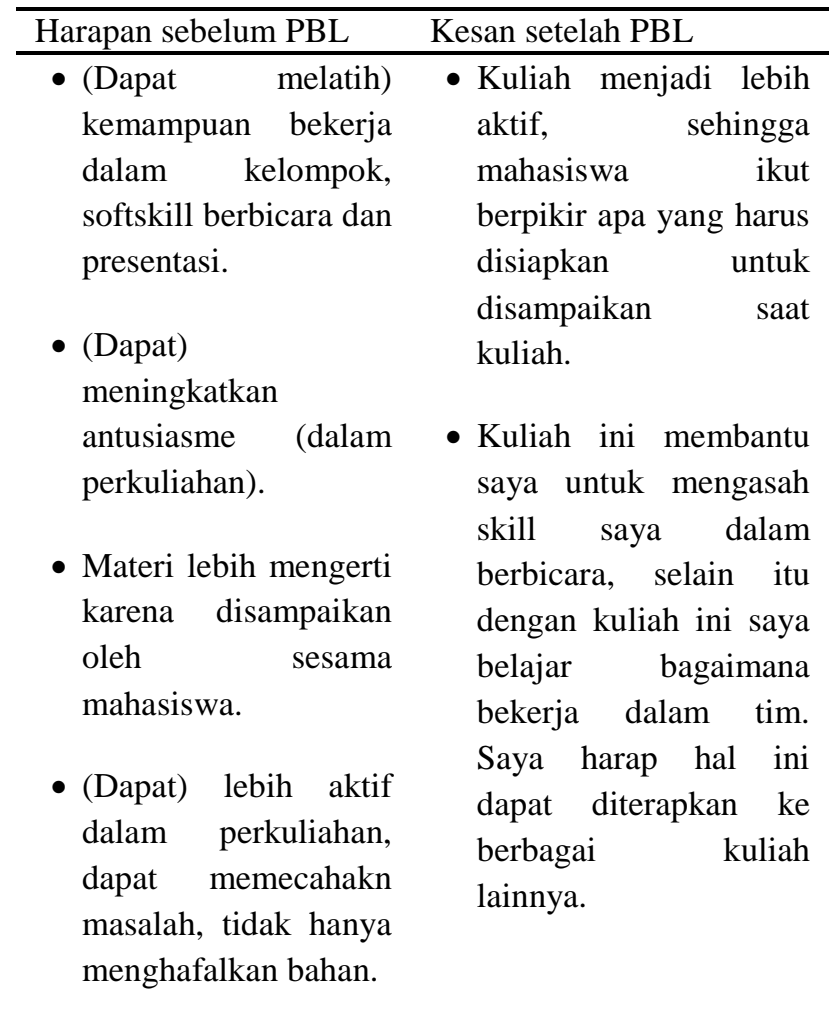




\section{Ucapan Terima Kasih}

Kegiatan pembelajaran berbasis masalah ini dibiayai oleh Hibah Pengembangan Metode Pembelajaran Pusat Inovasi Pembelajaran (PIP) UNPAR dengan kontrak No. III/PIP/201701/023-I. Penulis mengucapkan terima kasih atas bantuan pembiayaan yang diberikan.

\section{Daftar Pustaka}

Felder, R. M., \& Brent, R. (2003). Designing and teaching courses to satisfy the ABET engineering criteria. Journal of Engineering Education, 92(1), 7-25.

IChemE. (2017). Accreditation of chemical engineering programmes. Diakses tanggal 5 Agustus 2018 dari http://www.icheme.org/ /media/Docum ents/icheme/Membership/Accreditation /Accreditation $\% 20$ guidance $\% 20 \mathrm{~V} 20 \%$ 20Final\%2011\%20Aug\%202017.pdf

Larson, L. C., \& Miller, T. N. (2012). 21st Century Skills: Prepare Students for the Future. Kappa Delta Pi Record, 47(3), 121-123.

Novak, S., Shah, S., Wilson, J. P., Lawson, K. A., \& Salzman, R. D. (2006). Pharmacy Students' Learning Styles Before and After a Problem-based Learning Experience. American Journal of Pharmaceutical Education, 70(4), Article 74.

Powell, L. A. (2009). The Role of Learning Styles in Student Evaluations of a Problem-based Learning Course. Transformative Dialogues: Teaching \& Learning Journal, 2(3), 1-15.

Riechmann, S. W., \& Grasha, A. F. (1974). A Rational Approach to Developing and Assessing the Construct Validity of a Student Learning Style Scales Instrument. The Journal of Psychology: Interdisciplinary and Applied, 87(2), 213-223.
Santoso, M., Putra, A., Muhidong, J., Sailah, I., Mursid, S., Rifandi, A., Endrotomo. (2015). Paradigma Capaian Pembelajaran. Direktorat Jendral Pembelajaran dan Kemahasiswaan Kementerian Riset, Teknologi, dan Pendidikan Tinggi Republik Indonesia 